\title{
First Report of Daylily Leaf Streak Caused by Kabatiella microsticta on Hemerocallis spp. in Norway
}

\begin{abstract}
Gunn Mari Strømeng and May Bente Brurberg, Bioforsk - Norwegian Institute for Agricultural and Environmental Research, Plant Health and Plant Protection Division, N-1430 Ås, Norway; Eva Vike, Norwegian University of Life Sciences, Department of Plant and Environmental Sciences, N-1432 Ås, Norway; and Venche Talgø, Bioforsk - Norwegian Institute for Agricultural and Environmental Research, Plant Health and Plant Protection Division, N-1430 Ås, Norway
\end{abstract}

Accepted by publication 13 February 2015. Published 4 March 2015.

Strømeng, G. M., Brurberg, M. B., Vike, E., and Talgø, V. 2015. First report of daylily leaf streak caused by Kabatiella microsticta on Hemerocallis spp. in Norway. Plant Health Progress doi:10.1094/PHP-BR-14-0022.

Daylilies (Hemerocallis spp.) are herbaceous perennials that are used extensively as ornamentals in public and private gardens worldwide. In autumn 2009, distinct leaf spots (Fig. 1) were observed for the first time on H. lilioasphodelus (yellow daylily) and hybrid cultivars of Hemerocallis in the park at the Norwegian University of Life Sciences at Ås in southeastern Norway. Because the leaf spots continued to affect the ornamental value of the daylilies in subsequent years, further investigations were undertaken in 2012 and 2013. Symptoms appeared in late May on the oldest leaves at about the same time as flowering started in the earliest of the cultivars. The first visible leaf spots were small and round with a water-soaked appearance, and emerged both at the leaf margin and in the center of the leaves. The leaf spots became brown as they enlarged, and affected leaves often started to wilt from the leaf tips. Eventually, most leaf spots turned grey in the center, while the margins remained brown. By mid-July, conspicuous leaf spots had developed in all the examined daylilies. Leaf spots would eventually coalesce to give a streaky appearance. The disease did not cause death of the plants, but severely affected their aesthetic value. Leaves with symptoms were incubated in high humidity at $22 \pm 1{ }^{\circ} \mathrm{C}$. Sporulation similar to that observed in 2009 was found in the leaf spots after two days (Fig. 2). Spores from yellow daylily and cvs. Aureole, Sammy Russell, and Tejas were transferred to potato dextrose agar (PDA), and yielded identical, pale pink to orange colonies with white margins and a shiny appearance (Fig. 3A). 'Earliana' also showed symptoms, but attempts to isolate spores from this host did not result in fungal growth. Cultures eventually ( $>14$ days) turned darker from the center of the colonies (Fig. 3B). Spores from leaf spots and in culture were one-celled, hyaline, smooth, elliptic to fusiform, and often slightly curved (Fig. 4A). In the leaf spots, conidia were formed on conidiophores with swollen tips (Fig. 4B). Spores from two six days old cultures (PDA, $22 \pm 1^{\circ} \mathrm{C}$ ) and from a leaf lesion measured 4.1-(6.7)-11.3 × 1.1-(2.1)-3.4 $\mu \mathrm{m}$ $(\mathrm{n}=100)$ and 4.9-(7.1)-11.1 × 1.3-(2.2)-3.5 $\mu \mathrm{m}(\mathrm{n}=50)$, respectively. Colony diameter after seven days in darkness on PDA at $14,20,22,24,26$, and $28^{\circ} \mathrm{C}$, were $24.5,49.8,56.3,60.0$,
68.8 , and 45.3 , respectively $(\mathrm{N}=3)$. Morphological and colony characteristics were similar to those reported for Kabatiella microsticta Bubak (syn. Aureobasidium microstictum) (Bai, Han, et al. 2012; Leahy and Schubert 1996; Yoshikawa and Yokoyama 1987). K. microsticta was also morphologically identified in leaf spots on cvs. Corky, Crimson Pirate, and Joan Senior, and on the species $H$. citrina, in the University park. Sequencing of the ITS region of the rDNA from the isolates from yellow daylily and cv. Tejas, amplified by using the primers ITS4 and ITS5 (White, Bruns, et al. 1990), resulted in a 565 bp sequence which was $99.8 \%$ similar to that of $K$. microsticta HX4 from China (GenBank Accession No. HE798177.1 (Bai, Han, et al. 2012). The appearance and development of leaf spots were investigated on yellow daylily, cvs. Aureole, Earliana, Sammy Russell, and Tejas. Koch's postulates were carried out on potted plants of cv. Corky obtained from a commercial garden center. Four plants were inoculated with an isolate from $H$. lilioasphodelus, and four plants with an isolate from cv. Tejas. Spore suspensions $\left(10^{6}\right.$ conidia per ml distilled water) were sprayed to runoff. Four plants were sprayed with distilled water as control. The second youngest, fully developed leaf in each plant was punctured along the mid rib using a sterile needle prior to inoculation. After inoculation, plants were covered with a double layer of white plastic for $24 \mathrm{~h}$ to stimulate infection. The plants were kept in a well-ventilated high plastic tunnel (mean temperature $18.2^{\circ} \mathrm{C}$ ) for the duration of the experiment. One week after inoculation, narrow, necrotic areas, $1 \mathrm{~mm}$ in diameter had developed around the punctured tissues. After three weeks, symptoms also developed on one to two leaves that had not been artificially wounded before inoculation. K. microsticta was reisolated from leaf spots on the inoculated plants. In Norway, the disease has thus far only been confirmed at Ås. Daylily leaf streak has previously been reported from Japan (Yoshikawa and Yokoyama 1987), United States (Leahy and Schubert 1996), and China (Yoshikawa and Yokoyama 1987). If the disease becomes widespread in Norway, it may severely reduce the ornamental value and thus the use of daylilies in gardens and landscape plantings. 


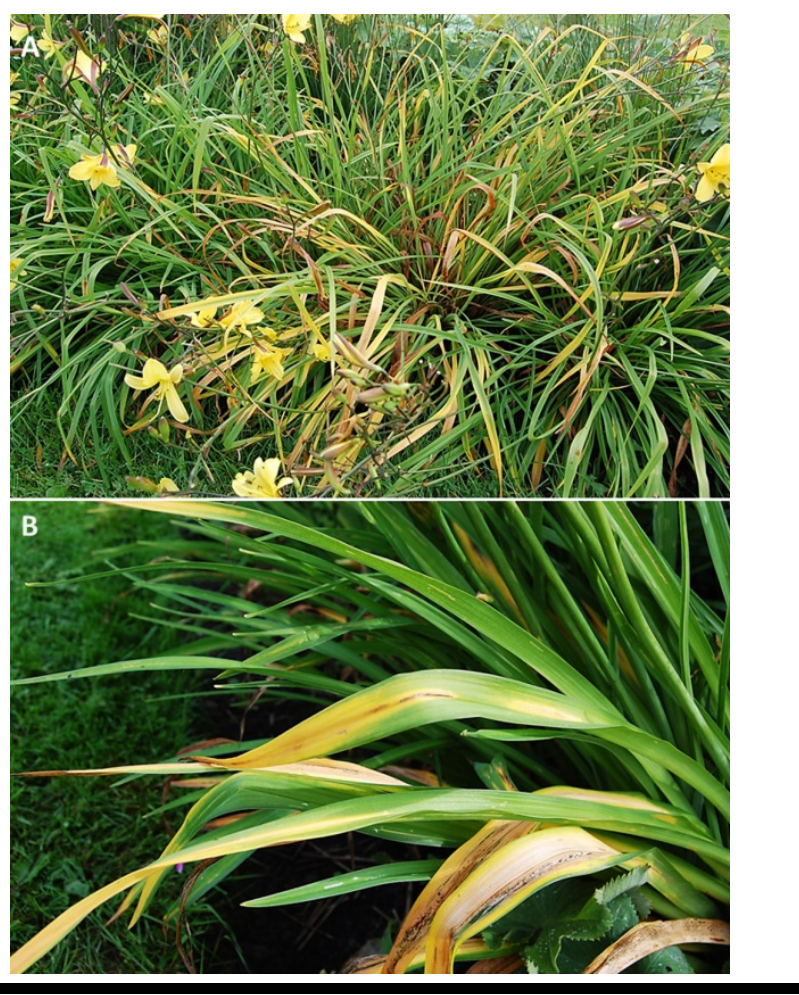

FIGURE 1

Hemerocallis cvs. Corky (A) and Joan Senior (B) infected by Kabatiella microsticta in the university park at Ås, Norway, 5 August 2009. Photos courtesy Eva Vike.
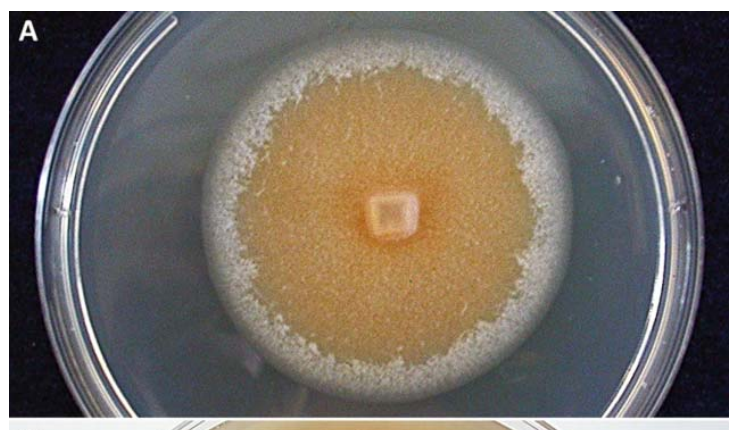

B

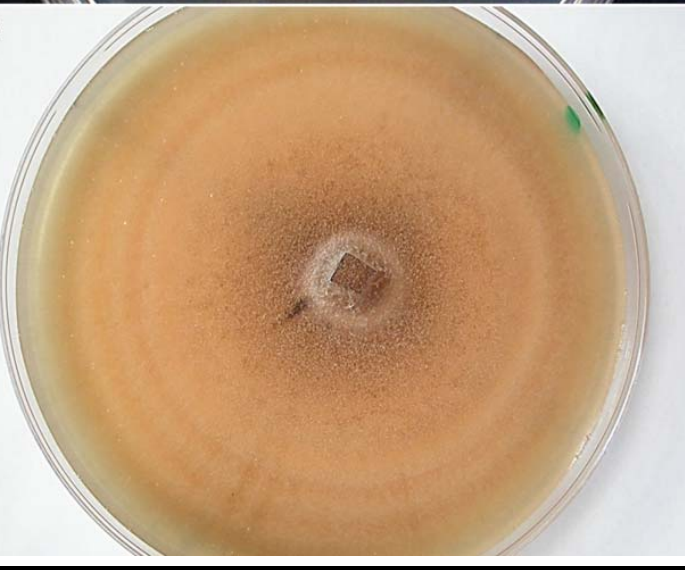

FIGURE 3

Kabatiella microsticta grown on PDA in darkness at $22 \pm 1^{\circ} \mathrm{C}$ after seven days (A) and after 15 days (B). Photos courtesy Gunn Mari Strømeng and Venche Talgø.
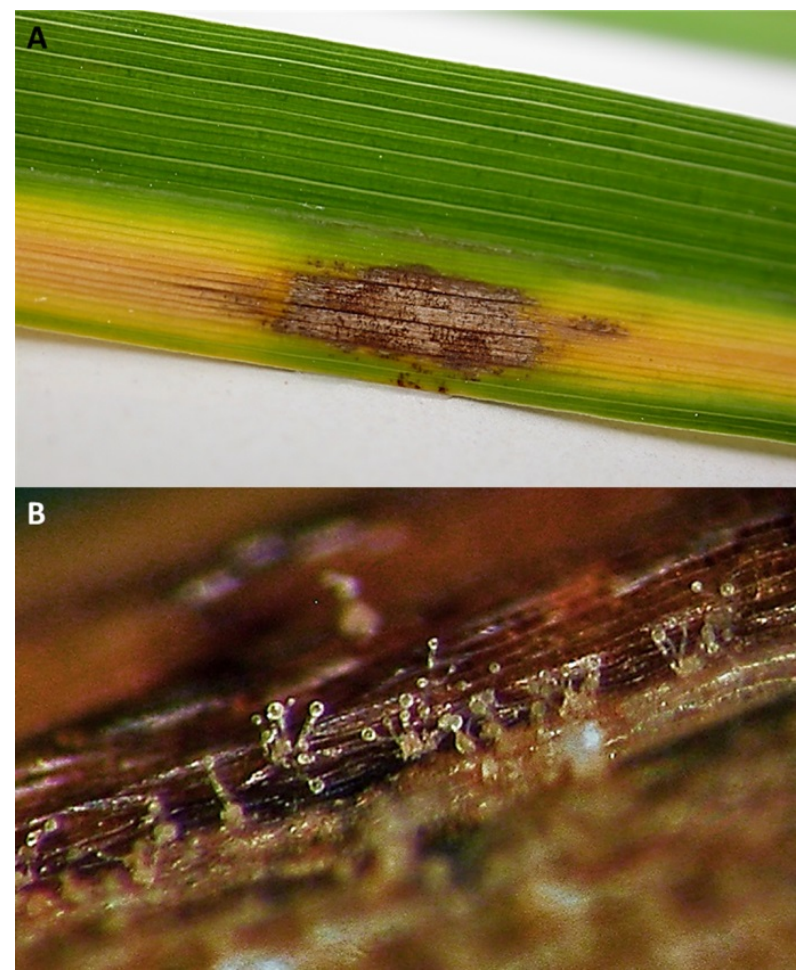

\section{FIGURE 2}

Leaf spot on naturally infected Hemerocallis cv. Tejas (A), and a closeup of the sporulation of Kabatiella microsticta in the leaf spot (B). Photos courtesy Venche Talgø and Gunn Mari Strømeng.

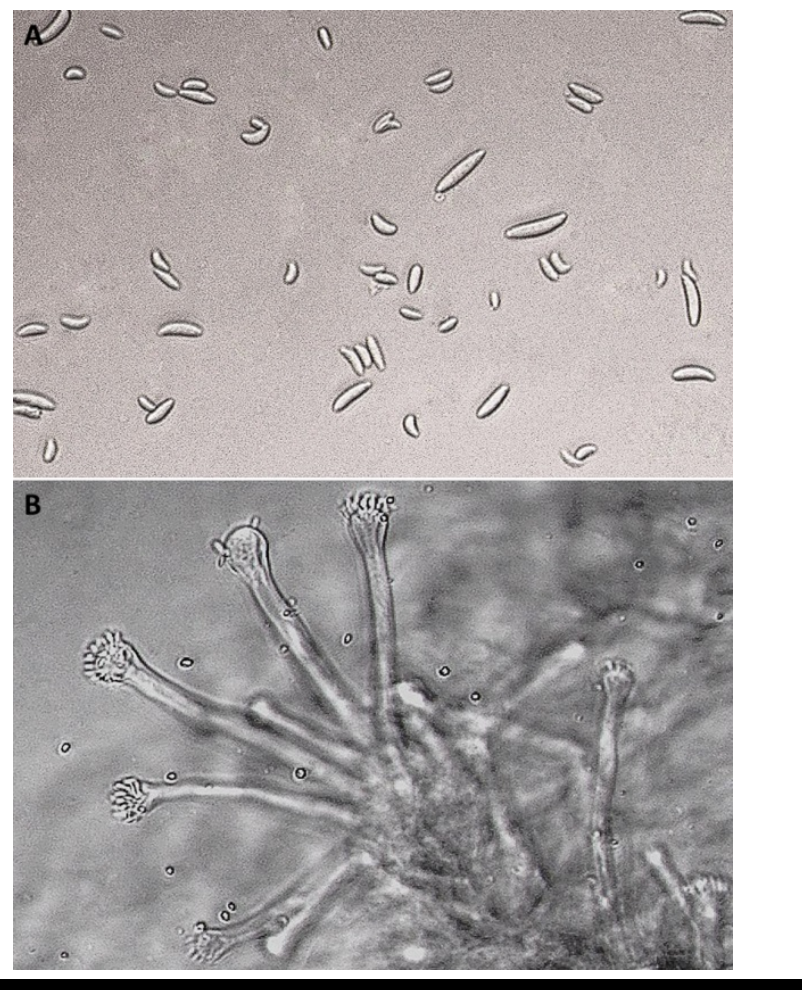

FIGURE 4

Kabatiella microsticta from naturally infected Hemerocallis cv. Tejas after three days incubation in high humidity at $22 \pm 1^{\circ} \mathrm{C}$. Conidia (A) and conidiophores with swollen tips (B). Photos courtesy Gunn Mari Strømeng. 


\section{LITERATURE CITED}

Bai, Q. R., Han, S., Xie, Y. Y., Dong, R., Gao, J., and Li, Y. 2012. First report of daylily leaf streak caused by Kabatiella microsticta in China. Plant Dis. 96:1579.

Leahy, R. M., and Schubert, T. S. 1996. Daylily leaf streak. Plant Pathol. Circ. 376. FDACS, Division of Plant Industry, Gainesville, FL.
Yoshikawa, M., and Yokoyama, T. 1987. Leaf blight of daylily caused by Aureobasidium microstictum (Bubak) W. B. Cooke. Annu. Phytopathol Soc. Jpn. 53:606-615.

White, T. J., Bruns, T., Lee, S., and Taylor, J. W. 1990. Amplification and direct sequencing of fungal ribosomal RNA genes for phylogenetics. Pages 315-322 in: PCR Protocols: A Guide to Methods and Applications, M. A. Innis, D. H. Gelfand, J. J. Sninsky, and T. J. White, eds. Academic Press Inc., New York. 